\title{
Introduction: Recognition between Anti- and Pro-imperial Readings
}

\begin{abstract}
Paul opposed Rome with Christ against Caesar, not because that empire was particularly unjust or oppressive, but because he questioned the normalcy of civilization itself, since civilization has always been imperial, that is, unjust and oppressive. ${ }^{1}$
\end{abstract}

This is how John Dominic Crossan and Jonathan L. Reed positioned Paul in their In Search of Paul: How Jesus' Apostle Opposed Rome's Empire with God's Kingdom. Several scholars have pronounced views similar to those of Crossan and Reed, not only on Paul but also on the New Testament as a whole. The scholarly situation can easily be grasped by reading, for example, Judy Diehl's tripartite review on recent anti-imperial readings of the New Testament. ${ }^{2}$ Roland Boer puts it illustratively:

The fact that so many books published in the last few years on the New Testament have "empire" somewhere in the title is an indication of a significant shift in scholarship. Four streams have come together to form what is now a wide and full river: older Marxist-inspired studies that have sought the historical conditions of a rebellious movement, liberationtheological approaches to the Bible, more recent postcolonial approaches and the growing sense (not new in itself) that the New Testament cannot be understood without considering its place within the Roman Empire. A significant feature of many of these studies is that they find deeply antiimperial themes in the biblical texts. Or at least one can find, they argue, a consistent anti-imperial theme running through them. Invariably, the comparison is made with our own times, whether it is the imperialism of the United States, or the global ravages of transnational corporations, or the profound difference between the majority of impoverished peoples of the world and the small number of the obscenely rich. ${ }^{3}$

1 Crossan and Reed 2005, x-xi.

2 Diehl 2011; 2012; 2013. See also, e.g., Barclay 2011, 364-365.

3 Boer 2013, 181-182. 
As Boer points out, these studies are often tinged by an impulse for modern applications. ${ }^{4}$ This is also the case with Crossan and Reed, who ask: "To what extent can America be Christian? We are now the greatest postindustrial civilization as Rome was then the greatest preindustrial one. That is precisely what makes Paul's challenge equally forceful for now and as for then, for here as for there, for Senatus Populusque Romanus as for Senatus Populusque Americanus." ${ }^{5}$ Basically, there is nothing wrong in these intentions to present modern applications. It is a problem if a reading pretends to be historical but is actually steered by modern goals. I like to point out the split between "what it meant" and "what it means," as Krister Stendahl once highlighted. ${ }^{6}$

As far as is hermeneutically possible, scholars should allow the text to communicate its own intentions, even if its message is strange or displeasing - and there is at least one displeasing passage in the New Testament, Romans 13:1-7. Roland Boer aptly states that it is "the stumbling block ... for those who interpret the New Testament as an anti-imperial and anti-colonial collection of texts." 7 The discomfort of scholars reading this passage is almost tangible. I once again take Crossan and Reed as an example. In their book of 450 pages, they discuss these verses in just two pages. There is good reason to limit this discussion to a minimum. If one wants to write of an apostle opposing the Roman Empire, there is not much to say about Romans 13:1-7. It is another matter, however, for the reader to get an accurate picture of what Paul thought of the Empire without a close look at Romans 13:1-7. This passage is the only one in Paul's epistles where he intentionally speaks about the state.

The anti-imperial reading finds its home mainly in the UsA. In my opinion, such a reading reflects the American political tradition. Stephen Kalberg (referring to Max Weber) notes that the Puritan tradition, which is so effective in the USA, is suspicious or even hostile toward human authority. The Protestants of the $17^{\text {th }}$ century believed that "should rulers violate God's decrees, the faithful stood under religious obligation to protest against and overthrow such illegitimate and unjust authority." ${ }^{8}$ One can easily see the same tradition behind the US Declaration of Independence.

We hold these truths to be self-evident, that all men are created equal, that they are endowed by their Creator with certain unalienable Rights,

4 See, e.g., Diehl's articles; Lehtipuu and Labahn 2015, 8; Barclay 2011, 367.

5 Crossan and Reed 2005, xi.

6 Stendahl 2000, 70 (originally 1962).

7 Boer 2013, 179-180.

8 Kalberg 2016, 43 (original emphasis). 
that among these are Life, Liberty and the pursuit of Happiness ... whenever any Form of Government becomes destructive of these ends, it is the Right of the People to alter or to abolish it, and to institute new Government, laying its foundation on such principles and organizing its powers in such form, as to them shall seem most likely to effect their Safety and Happiness.... [W] hen a long train of abuses and usurpations, pursuing invariably the same Object evinces a design to reduce them under absolute Despotism, it is their right, it is their duty, to throw off such Government, and to provide new Guards for their future security.

The Declaration supports Americans to maintain sharp eyes to see any limitations placed on their freedom. It promulgates the continuous "Right of the People" to alter or to abolish governments. I suggest that American eyes also explain the recent anti-imperial reading of the New Testament. For those raised in American culture, anti-imperialism is the given position. Crossan and Reed were educated into this same culture, but their American eyes have turned a critical gaze toward the USA. These are self-critical eyes, but they are still the same culturally American eyes in search of freedom from tyranny. Europe trusts more in the centralized state, although it has had its own turmoils. It is noteworthy that the Declaration blames the king of Great Britain for establishing "an absolute tyranny." Such hard words naturally had a reason within the historical situation in which they were composed, but they also reflect certain differences in the political culture on both the western and eastern banks of the Atlantic Ocean.

This difference is especially true when the USA is compared to Northern Europe, where the Lutheran political tradition recognizes Romans 13:1-7 as one of the culturally key texts, which repels any revolutionary spirit. ${ }^{9}$ To my Northern European eyes, the US Declaration of Independence resembles the constitution proposed by the Finnish revolutionaries in 1918. They were inspired by the Bolshevik revolution in Russia and stated in their constitution that, should the parliament remove the constitution, "let the people arise and dissolve that parliament."10 The similarity between the US Declaration and the Finnish red constitution is not accidental. Besides the fact that the authors of the red constitution consulted US constitutional documents, ${ }^{11}$ they both belong to the apocalyptic tradition. The presence of apocalyptic themes in

$9 \quad$ Nelson 2017, 87-105; Huttunen 2019.

$10 \S 43$ (my translation from Finnish).

11 Rinta-Tassi 1986, 33 o. 
American political culture is conspicuous, ${ }^{12}$ like it is in Marxism. The Marxist philosophy of history is a secularized modification of Jewish-Christian apocalypticism. ${ }^{13}$ Even the sentiments sound similar, as the anarchist Emma Goldman once noted when intuitively depicting the Bolsheviks as puritans: "The Bolsheviki were social puritans who sincerely believed that they alone were ordained to save mankind."14 Americans and Bolsheviks are in many respects strange bedfellows, but the revolutionary tendency to oppose the powers that be is similar. Northern Europe has been a hard soil for such tendencies. The religious heritage of Romans 13:1-7 resulted in the fact thatborrowing the words of Anthony F. Upton- "from the Finnish revolution some vital spark was missing."15 Revolution is an anomaly in Finnish political culture, and in the other Nordic countries revolution never broke out. To me, therefore, the anti-imperial reading appears somewhat strange.

After recognizing the differences between the political traditions on both sides of the Atlantic Ocean, it probably comes as no surprise that European scholars are somewhat critical toward the anti-imperial reading of the New Testament. The Belgian scholarJoseph Verheyden notes that in the anti-imperial readings there is a risk of interpreting specific passages too exclusively "in light of the overall thesis at the cost of obscuring the immediate context in which a particular passage occurs." Verheyden gives an elaborate example of an antiimperial interpretation of the yoke analogy in the Gospel of Matthew (11:28-30). He concludes that the result is "too simplistic" and that "early Christianity cannot be captured under this sole header," namely anti-imperialism. ${ }^{16}$ In a similar vein, Outi Lehtipuu and Michael Labahn, the European editors of People under Power, describe the essays in the book as follows:

The task of the present volume is to show that the topic is more complicated than often assumed and that relations between the empire and the

12 See, e.g., Jewett and Lawrence 2003.

13 See, e.g., Zimdars-Schwartz and Zimdars-Schwartz 1998, 286-289; Baumgartner 1999, 201-202. Boer (2010; 2012, 289-29o) is somewhat suspicious of this view, but I think that the numerous similarities in the apocalyptic and Marxist visions of history cannot be accidental. Boer notes that Engels' interest in Revelation had not so much to do with the historical vision but the revolutionary spirit. I have no reason to doubt this claim. However, I guess that the Marxist philosophy of history finds its apocalyptic roots through several adaptations. Hegel was the immediate predecessor.

14 Goldman 1923, 112.

15 Upton 1980, 395. I just need to add that in the 1930s, the Nordic countries were resistant also to right-wing politics. The Nazis received acceptance in the multi-confessional Germany, but not in the Nordic countries (Nelson 2017, 100-104).

16 Verheyden 2014, xvi-xxi. 
Jews and Christians living within its limits cannot simply be described in terms of conflict, clash, and opposition. As several recent studies have made clear, early Christianity and early Judaism were diverse movements that included various versions of how to be and live as a Christian or Jew. The attitudes toward the Empire also varied and differed both geographically and temporally. There is no such thing as the Christian or the Jewish response to imperial rule and ideology. The attitudes of peasants living in the Roman Galilee, for example, were not the same as those of the urban dwellers living outside of the region who wrote about them. The further the Jesus movement expanded, the more diversified it became, while reactions toward the Roman authorities proliferated. Moreover, the Roman world was no less diverse; the faces of the empire did not look the same for all its inhabitants. This profound diversity is mirrored in manifold ways in the ancient sources and is also reflected in the essays of this volume. ${ }^{17}$

European scholars seem to be much more cautious with the anti-imperial interpretations than the Americans. ${ }^{18}$ However, it would also be a mistake to pass anti-imperial readings off as pure eisegesis. One can even find sympathy for anti-imperial readings from surprising quarters. For example, Leopold von Ranke, who is famous for the paradigm he introduced into subsequent historical research, supported an anti-imperial reading. Ranke was a conservative thinker who had been ennobled by the Prussian king and had no apparent reason to introduce an anti-imperial agenda into the New Testament texts. In his writings, however, he constructed a political problem at the center of early Christianity. Obedience toward the Empire and toward the Kingdom of God ran into an undeniable conflict, Ranke claims. ${ }^{19}$

Denying the anti-imperial potential of the New Testament is meaningless, because right at the heart of Christianity lies a person executed by the Roman authorities. In his First Letter to the Corinthians, Paul prefers to know nothing but "Jesus Christ, him crucified." He continues by proclaiming that it was "the rulers of this age" who "crucified the Lord of glory" (1 Cor 2:2,8). However, with the power structure changing, Paul is convinced that Christ is alive and he will give the kingdom to God after destroying "every ruler and every authority and power" (1 Cor 15:24). This is not only an anti-Roman claim. This is an

17 Lehtipuu and Labahn 2015, 9. I would like to mention Anders Klostergaard Petersen's (2015) chapter in People under Power, as it elegantly exemplifies balanced cautiousness toward anti-imperial readings.

18 There are surely exceptions to this European/American divide (see, e.g., Harrill 2011), but it does indeed reflect a general pattern.

19 Ranke 1883, 182, 184. 
anti-imperial claim, anarchistically directed against any political use of power, "the normalcy of civilization itself," as Crossan and Reed put it in the epigraph that heads this chapter. This did not remain the case only at the theoretical level but was realized in actual tensions with the contemporary political powers of the day. Paul was put to death in Rome, and this was not an isolated incident. Even non-Christian sources report on tensions between the early Christians and Roman society. Describing Nero's persecution in Rome in the 6os CE, Tacitus maintains that the Emperor falsely blamed Christians for the burning of the city, but that Christians got what they deserved anyway (Tacitus, Ann. 15.44). Suetonius praises Nero's response as a good action (Nero 16). And Pliny the Younger reports on his problems with Christians in Asia Minor (Ep. 10.96). ${ }^{20}$

Both the Christian and the Roman sources demonstrate the real tensions that existed between Christians and Roman society. Therefore, aside from some overly daring interpretations of single statements exemplified by Verheyden, what - if anything - is unsound or amiss in the anti-imperial readings? I claim that the overall thesis is too daring: the early Christians and Roman society were not in constant tension. Even according to Verheyden, the picture is a "much more colourful one and cannot fully be grasped under this one perspective."21 In other words, the early Christians were not only antiimperial. There is also much evidence of pro-imperial perspectives in the early Christian sources. ${ }^{22}$ How can this be understood? Were there different kinds of Christians? Absolutely. Commenting on the anti-Roman message in Revelation, Henk Jan de Jonge puts it as follows:

The anti-Roman stance of the author of Revelation need not be taken as representative of early Christianity in Ephesus, or in Asia, or in Anatolia, at the beginning of the second century CE. On the contrary, 1 Peter 2:13-17 ... and 1 Tim. 2:2, possibly also written in Ephesus at the beginning of the second century, show that when Revelation was written, other Christians in Asia Minor succeeded in coming to terms with Rome. That was indeed the more usual attitude of Christians towards Rome, at least in

20 Cook (2010) presents a careful reading of these texts. It may be added that the historicity of Nero's persecution has been recently questioned by Shaw $(2015,2018)$, but without success (Jones 2017; van der Lans and Bremmer 2017). From my point of view, it is essential to note that the accounts themselves attest to tensions at least in Tacitus' own time in the beginning of the second century. Even Shaw does not deny this.

21 Verheyden 2014, xxii.

22 Boer 2012, 293: "We do not find that the Bible and theology are squarely with the oppressors and powers-that-be, nor do we find it gives voice solely to the aspirations of the downtrodden. Rather, in that vast mix of literature and thought, we find both." 
the first century CE, as appears from Paul (Rom. 13:1-7), Mark (12:17), and 1 Clement $(61: 1-2) .^{23}$

One can even find pro- and anti-imperial tendencies expressed by a single author. I remarked on the difference between Paul's sayings in Romans and in 1 Corinthians above. On the other hand, in the Book of Revelation, Christ finally gets the upper hand as a military conqueror, which bears a striking resemblance to Roman ideology. Thus, it is a simplification to label early Christianity, the New Testament, or even an individual author anti- or proimperial. How might this tension in political attitudes be resolved or explained? John S. Kloppenborg has made several helpful observations based on postcolonial studies. His material deals with the figure of the Judge in $Q$, but his insights bear a more general validity. Kloppenborg notes that the imitation of the dominant discourse by the subaltern has two functions. First, "the subaltern adopts the language of the dominant culture in order to reduce alterity." Kloppenborg presents Romans 13:1-7 as an example. Second, the imitation of the dominant discourse is incomplete. By partial imitation, the subaltern "both disguises herself as compliant, and creates room for identity in a new discursive space."24 I argue that the anti-imperial reading of the New Testament cannot grasp this complexity. It is too indulgent of a strict opposition between the oppressor and the oppressed to do justice to the varied modes of contact between the hegemonic and the non-hegemonic. It narrows this interaction into a conflict. In her Imperial Eyes, Mary Louise Pratt prefers the term "contact zone" to make room for the agency of the dominated:

By using the term "contact," I aim to foreground the interactive, improvisational dimensions of colonial encounters so easily ignored or suppressed by diffusionist accounts of conquest and domination. A "contact" perspective emphasizes how subjects are constituted in and by their relations to each other. It treats the relations ... not in terms of separatedness or apartheid, but in terms of copresence, interaction, interlocking understandings and practices, often within radically asymmetrical relations of power. ${ }^{25}$

One can easily see that in Romans 13, Paul is addressing an audience that does not have authority within the state. The addressees are subjects, like Paul

\footnotetext{
23 De Jonge 2002, 140.

24 Kloppenborg 2014, 181.

25 Pratt 1995, 7.
} 
himself, "within radically asymmetrical relations of power." Yet, Paul does not offer resistance as a cure. Instead, he creates a new discursive space. This is what Pratt calls "autoethnography" or "autoethnographic expression." She uses "these terms to refer to instances in which colonized subjects undertake to represent themselves in ways that engage with the colonizer's own terms." Autoethnographic texts are constructed in response to or in dialogue with the colonizing representations. ${ }^{26} \mathrm{My}$ aim is to show how Paul's thoughts in Romans 13 interact with Greco-Roman mainstream thinking. His admonition to obey is a piece of political realism in a society where opposition would have led to disaster. However, Paul creates a discursive space where a Christian identity can breathe and keep distance from the authorities. His message was neither that of a political revolutionary, nor that of an eager loyalist. I question the paradigm of polar opposites; I question that the early Christians were either resisting the authorities or conforming to them. There are many more positions, which I gather under the concept of "recognition." Here I follow the heuristic findings of Risto Saarinen in his recent book Recognition and Religion. Recognition describes a situation in which the parties can come to terms with each other in several ways, that is, without full agreement. Recognition resembles tolerance, but these concepts are not synonymous:

While both recognition and toleration assume a lasting disagreement between two or more parties, the attitude of recognizing another person or group typically means something 'more' than mere toleration. This 'more' may consist in a commitment to work together, respect other convictions, and approve a general societal or ideological framework in which the coexistence takes place. ${ }^{27}$

Recognition does not have the prerequisite that the parties be equal. Instead, there are cases of downward and upward recognition. ${ }^{28}$ Upward recognition is an act of submission to an authority, something that clearly happens in Romans 13. This is important for my study, because Christians were clearly in the minor position in the vast Empire; they granted recognition to the authorities and the society of which they were a part. At the same time, however, they sought recognition for themselves. Moreover, recognition can be mediated, such that the parties cannot recognize each other but they recognize a

26 Pratt 1995, 7 (original emphasis).

27 Saarinen 2016, 1.

28 Saarinen $2016,32-33,35-36$. 
third party, which can be, for example, a person or set of rules. ${ }^{29}$ For instance, Christians could be recognized as a philosophical school and, thus, in such a way, they were able to find a position in Greco-Roman culture, although the content of their thoughts was not recognized on their own merit. In this case, philosophy is mediating the recognition. Finally, one should note that the process of recognition does not always appear in concepts or conceptions, but also within actual practices. ${ }^{30}$ An example of recognition in practice is Christians who were in service to the Roman imperial army. Service itself proved recognition of the Empire from the side of the Christian soldiers, while the Empire recognized the Christian soldiers as its legitimate servants. As a heuristic tool, the concept of recognition is employed to avoid black-and-white interpretations of Christian-Empire relationships. The alternatives are not only full denial and full acceptance but much more in-between these two extremes. In this book, I discuss the relationship between the early Christians and the Roman Empire on three levels: cultural, political, and practical.

In Chapter 2, I concentrate on the cultural level. There is a long tradition attempting to split Christian religiosity from ancient philosophy. In contrast to that, I show that the contact zone between them was not only hostile, but also a place for mutual recognition. In section 1 of this chapter, I concentrate on some non-Christian philosophers of the second century. A close reading of the accounts of Christians by Epictetus, Marcus Aurelius, Lucian, and Galen leads me to the conclusion that these philosophers saw Christians in the category of philosophers. In this way, they recognized Christians as a rival philosophical school and a legitimate group in society. The recognition was real, despite the fact that the philosophers found deficiencies in Christian teachings. In section 2, I claim that non-Christian philosophers recognized Christians as philosophers, after the latter sought recognition as such. I start with Tertullian's famous sentence on Athens and Jerusalem. Its heightened antagonism between ancient philosophy and Christianity should be seen as a rhetorical exaggeration. I claim that Tertullian's sentence describes neither his own position nor that of the biblical passages (Acts 17, $\mathrm{Col} \mathrm{2)}$ ) he uses to warrant the antagonism. I also show how Paul's words against human wisdom in 1 Corinthians 1-2 participate in the contemporary philosophical discourse of the day, although scholars have routinely read the text as a misrecognition of philosophy. Later in the same epistle, in 1 Corinthians 7 , Paul shows clear affinities with Stoicism. I conclude that philosophical elements are present already in the earliest Christian documents and, thus, philosophy forms a recognized

29 Saarinen 2016, 33, 41.

30 Saarinen 2016, 34-35. 
part of the Christian identity, not a later lapse from pristine piety, as Tertullian and others have claimed.

In Chapter 3, I deal with the political level, including the theme I have already touched on above. I take a fresh look at Romans 13:1-7 and put it into the context of ancient political philosophy. Instead of looking for the ancient theories of ideal kings and political structures, I look at how ancient people constructed sources of power. I claim that the context of Paul's words on earthly authorities is the law of the stronger that has permeated ancient texts for centuries. The readers of Paul have always seen the theological edge: authorities are instituted by God. One has less often discussed how the institution can be identified. What is the hallmark of God's institution? In the social reality, it is the sword. According to the law of the stronger, power is a witness of divine favor. Paul seems to follow this pattern, providing a Jewish variant, which is also known from Josephus. There are no Roman gods, but rather the God of Israel showing His favor for the Empire. This was a theological explication for the ruthless political realism, with brutal force being the leading factor in political life. On the other hand, this was not all that Paul said on the topic. In reality, he was a kind of Christian anarchist waiting for the end of all human hierarchies. This eschatological expectation reflected by intraChristian morals and, during the centuries, the larger society. In this way, at least some eschatological hopes, which Marxists have criticized as a fantasy, have been gradually realized. This is the paradox of political quietism. In turn, the Marxist revolutions which ideologically stemmed from apocalypticism and aimed at realizing its hopes resulted in oppressive empires. I have framed this chapter around a discussion with Marxists and anarchists. I also note the ways that scholars and general audiences have tried to cope with the unlimited obedience of authorities required by Romans 13:1-7.

Chapter 4 deals with the practical level of recognition. This represents a vast area of topics to be studied. However, I have chosen to focus on the problem of Christian soldiers. What do we know of them in the first two centuries and what was their position among the early Christians? This part of my study is a voice from the margins, as there is little discussion on the topic, apart from the modern ethical discourse often lacking understanding of the ancient social world and the army as part of it. In section 1 of this chapter, I read the military characters presented in the gospels as part of the ancient social world. Unlike most modern studies seem to assume, military characters in the texts do not aim to present a moral stance vis-à-vis military service as such. They may reveal something about this matter, too, but this is not their function in the narrative. I suggest, rather, that the main factor in understanding military figures is the difference between rank-and-file soldiers and centurions. In the 
ancient sources, the former are mainly negative figures and the latter positive ones. The gospels seem to repeat this general view. This division was dependent on how the civil population experienced soldiers in their everyday life. The modern moral discussion has also narrowed the view on soldiers, as it has failed to see that the role of the army was broader than that of modern armies. This is not to say that there was never any moral discussion on military service in early Christianity. As I show in section 2 of chapter 4, many literate early Christian theologians shared the evasive or negative attitude of the philosophical authors of the time. Their statements should not be read as the Christian statements. Actually, they often betray the fact that some Christians served in the army and thereby recognized the Roman Empire on the practical level of their daily life. Despite occasional tensions, the army seemed more or less to recognize its Christian soldiers as legitimate servants of the Empire.

In the final chapter, I summarize the main results of my study. The aim of this book is to propose a balance against the black-and-white claims of resistance and conformism. The political history of the early Christians cannot be reduced into the positions of anti- or pro-imperialism. I claim that recognition is a good concept with which to analyze the variegated modes of interaction between the Roman Empire and the early Christians. 